\title{
Determination of Land Pollution with Heavy Metals along Sitnica River, Kosovo
}

\author{
Albona Shala Abazi', Fatbardh Sallaku², Shkëlzim Ukaj ${ }^{3}$, Pajtim Bytyçi, \\ Mimoza Hyseni Spahiu ${ }^{1 *}$
}

1 University "Haxhi Zeka", Faculty of Management in Tourism, Hospitality and Environment; University Haxhi Zeka, Str. UCK, 30000 Peje, Republic of Kosovo

2 Agricultural University of Tirana, Albania

3 Kolegji UBT, Prishtine, Kosovo

${ }^{4}$ South East European University, Faculty of Contemporary Sciences and Technologies, llindenska 335, Macedonia

*Corresponding author's e-mail: mimoza.hysenispahiu@unhz.eu

\begin{abstract}
The main river of the Kosovo valley is the Sitnica River, which collects a large number of streams, recipients of wastewaterfrom various urban and industrial centers. The blockage of Sitnica river with waste and non-regulation of the bedding of this river makes this river flood tens of acres of worked ground surface through its course, causing great damage every spring and autumn. Uncontrolled discharge of heavy metals into the contaminated terrestrial environments ensures their transfer to plants, animals and humans and results in an impact on the environment and public health. Determination of the heavy metals concentration level for the assessment of soil pollution along the Sitnica River course was also the main purpose of this study, which was carried out in 2016. For analysis, 8 soil samples were taken at depths of $30-50 \mathrm{~cm}$. From the analysis of the data it was noticed that the content of heavy metals such as $\mathrm{Zn}, \mathrm{Cd}, \mathrm{Pb}, \mathrm{Cr}$ in some analyzed samples exceeds the maximum allowed values. The findings indicate high values of metal pollution in the samples taken in meadows as well as the agricultural lands stretching around the river.
\end{abstract}

Keywords: pollution, heavy metals, land, Sitnica River.

\section{INTRODUCTION}

Heavy metals have important positive and negative roles in human life (Adriano, 1984; Slaveska et al., 1998; Divrikli et al., 2003; Dundar and Saglam, 2004; Colak et al., 2005; Oktem et al., 2005). Metals such as lead, mercury, cadmium, and copper are cumulative poisons, which cause environmental hazards and are reported to be exceptionally toxic (Ellen et al., 1990). Metals like iron, copper, zinc and manganese are essential for humans, since they play an important role in biological systems, but the essential heavy metals can produce toxic effects when their intake is excessively elevated (Schroeder, 1973; Mendil et al., 2005; Narin et al., 2005; Öztürk et al.,2011).
The soil nutrients include the essential and the non-essential heavy metals such as copper, iron, manganese or nickel and they have important roles in plant growth (Marschner 1995; Hagemeyer 2004). The heavy metal content of soil is dependent on both natural and anthropogenic sources in the local ecosystems. In turn, the natural forms are usually found in relatively low concentrations, in recent decades, the number and intensity of anthropogenic sources such as rubbish tips, smelter stacks, waste incineration fertilizers, vehicle emissions, agricultural waste and sewage sludge have increased the local environmental heavy metal concentrations (Bargagli 1998; Koch and Rotard 2001; Güleryüz et al, 2008). 
Sitnica is the main river of Fushë Kosova, which gathers a large number of ravines on the left and the right side. It is a recipient of the wastewater from various urban and industrial centres . It is a typical field river with a small slope and slow flow in months with abundant rainfall. Nonadjustment of this river and its blocking with waste makes this river overflow and inundate tens of hectares of worked land along its flow causing enormous damage every spring and autumn. During inflows, this river, covers a large part of the field; it has no stable bed and is characterized by the frequent occurrence of the bed change (Kastrati, 2014).

According to the previous research, the main source of agricultural land and the environment pollution in Kosovo with heavy metals is the industry. Although industrialization is inevitable, various devastating ecological and human disasters, which have continuously occurred over the years, implicate industries as a major contributor to the environmental degradation and pollution processes of various magnitudes. Industrial waste and emissions contain toxic and hazardous substances, most of which can be detrimental to the human health. These include heavy metals such as lead, chromium and mercury, and toxic organic chemicals such as pesticides, polychlorinated biphenyls (PCBs) polyaromatic hydrocarbons (PAHs), petrochemicals as well as phenolic compounds (Dan'azumi and Bichi 2010).

The indiscriminate discharge of chemical toxins, especially $\mathrm{Pb}, \mathrm{Cd}, \mathrm{Cr}, \mathrm{Co}$, etc. into the environment ensure their transfer into plants, animals and man and high concentration of heavy metals in irrigation waters could result in the death of crops, interfere with the uptake of other essential nutrients or form objectionable deposits on fruits and render the edible portion of plants toxic to human and grazing animals (Bichi 1999; Dan'azumi and Bichi 2010). Thus, in the natural environment, the concentration of heavy metals should be low. High concentration of heavy metals in contaminated environments impacts the environment and public health (Berglund et al., 1984).

The goal of this study was to determine the concentration of heavy metals for the assessment of land pollution along the flow of this A better view and more complete profile of the land pollution level along the Sitnica River with metals influenced by anthropogenic activity river is provided through this paper.

\section{MATERIALS AND METHODS}

The research on the agricultural lands and meadows was conducted along the flow of the Sitnica River to gain a true picture of pollution. A total of 8 land samples were taken, four of them were taken on the arable lands located close to the river, which use the water of Sitnica River for irrigation (Vojnovc, Plemetin in cultivated land, Pestovë dhe Mitrovicë before joining the Iber River), three samples in the meadows by the river (Grackë, Kuzmin dhe Plementin in uncultivated land) and a sample in a wooden area at the source of the river in Devetak. The samples were taken at $0-30 \mathrm{~cm}$ depth, up there where the major part of the root system of plants is developing. The analyses were conducted with the applied methods in the analytical laboratory of Kosovo Agricultural Institute which refer to international US EPA Method 3050B standards. The land samples collected at various locations throughout the valley of the river were analysed for such metals as $\mathrm{Pb}, \mathrm{Zn}, \mathrm{Cd}, \mathrm{Cr}, \mathrm{Cu}, \mathrm{Mn}, \mathrm{Fe}, \mathrm{Mn}, \mathrm{Sr}, \mathrm{K}, \mathrm{Ba}, \mathrm{Mo}$ and $\mathrm{Al}$ using the MP-AES 4200 - Agilent camera.

\section{RESULTS AND DISCUSSIONS}

Table 1 and Figures from 1 to 4 present the results pertaining to the content of metals in the soil samples analysed along the river Sitnica.

As can be seen from the table, the values of the content of metals in soil samples showed distinctness from one to another sampling place, $\mathrm{Cd}$ in the soil samples showed the values from $0.5-8.9 \mathrm{mg} / \mathrm{kg}$, compared to the Kosovo standards for maximum values allowed in sampling place before joining the Iber River, $\mathrm{Cd}$ exceeded the values more than three times. The $\mathrm{Cr}$ values varied from 13.1 to $106 \mathrm{mg} / \mathrm{kg}$, in the following sampling places: Vojnovc; Grackë, Kuzmin, Plementim in cultivated land and sampling place before joining the Iber River, the results were above the maximum allowed values. In the investigated samples, the variations of $\mathrm{Pb}$ are from 15.9 to $1148 \mathrm{mg} / \mathrm{kg}$, the values above allowed standards of this element are shown in the Grackë and before joining the Iber River (about 20 times higher than VML). Even the results of $\mathrm{Zn}$ in two sampling places in Kuzmin and sampling place before joining the Iber River exceeded the allowed values for Kosovo standards, Ba in the sampling place Grackë was over the critical point of 
Table 1. Results of soil samples analyses in metal compounds, $\mathrm{mg} / \mathrm{kg}$

\begin{tabular}{|c|c|c|c|c|c|c|c|c|}
\hline Metals & Devetak & Vojnovc & Gracka & Kuzmin & $\begin{array}{c}\text { Plemetin } \\
\text { uncultivated } \\
\text { land }\end{array}$ & $\begin{array}{c}\text { Plemetin } \\
\text { cultivated } \\
\text { land }\end{array}$ & Pestova & $\begin{array}{c}\text { Before } \\
\text { joining the } \\
\text { lber River }\end{array}$ \\
\hline $\mathrm{Cd}$ & 0.5 & 0.6 & 1.2 & 1.2 & 0.6 & 0.6 & 0.7 & 8.9 \\
\hline $\mathrm{Cr}$ & 13.1 & 65.5 & 57.7 & 106.0 & 32.6 & 98.4 & 49.2 & 58.2 \\
\hline $\mathrm{Pb}$ & 15.9 & 16.1 & 58.0 & 331.0 & 24.0 & 25.0 & 54.0 & 1148.0 \\
\hline $\mathrm{Sr}$ & 7.5 & 21.1 & 21.1 & 31.1 & 87.9 & 24.2 & 19.8 & 16.8 \\
\hline $\mathrm{Mo}$ & 3.2 & 10.4 & 10.9 & 11.8 & 9.6 & 10.8 & 10.1 & 13.1 \\
\hline $\mathrm{Cu}$ & 11.5 & 26.9 & 40.4 & 50.0 & 25.0 & 38.5 & 23.1 & 76.9 \\
\hline $\mathrm{Zn}$ & 23.1 & 62.5 & 101.9 & 361.1 & 53.2 & 97.2 & 83.3 & 870.4 \\
\hline $\mathrm{Ba}$ & 21.0 & 87.4 & 142.1 & 99.4 & 41.3 & 99.7 & 62.7 & 89.8 \\
\hline $\mathrm{Mn}$ & 237.5 & 587.5 & 975.0 & 1340.0 & 325.0 & 812.5 & 575.0 & 1820.0 \\
\hline $\mathrm{Fe}$ & 566.7 & 1566.7 & 1733.3 & 2033.3 & 633.3 & 1600.0 & 1033.3 & 4866.7 \\
\hline $\mathrm{K}$ & 415.0 & 1370.0 & 2356.0 & 1518.0 & 799.0 & 2314.0 & 1061.0 & 1268.0 \\
\hline $\mathrm{Al}$ & 2226.0 & 10560.0 & 12254.0 & 10545.0 & 5427.0 & 9230.0 & 4955.0 & 8012.0 \\
\hline
\end{tabular}

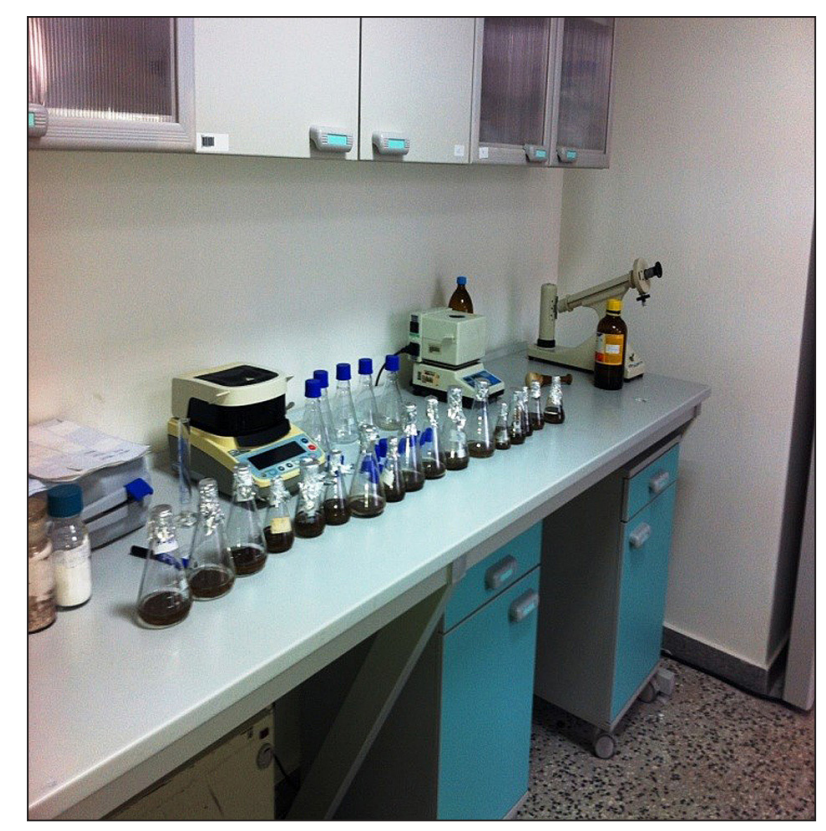

Figure 1. Appearance of the collected soil samples and their analysis

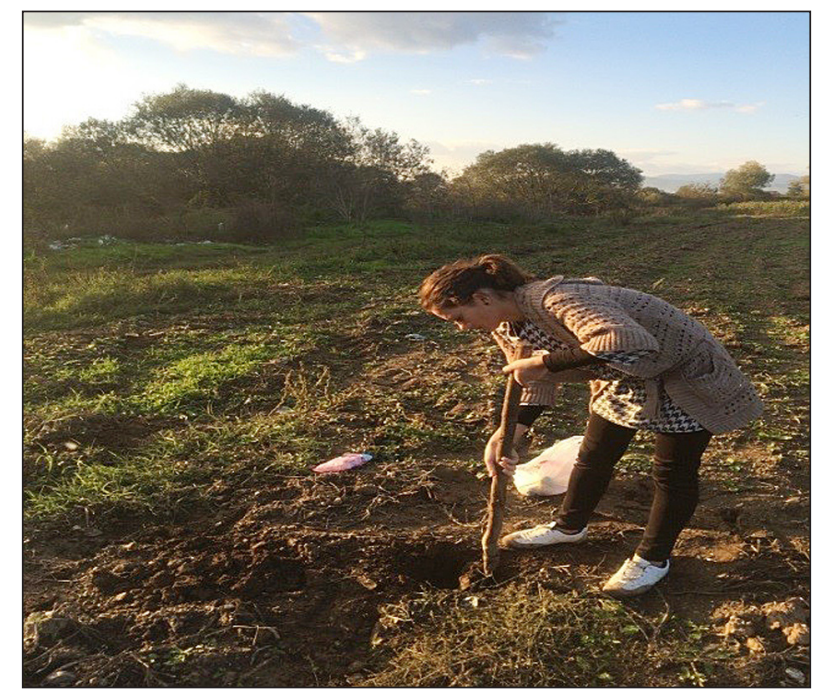

Figure 2 Contents of $\mathrm{Zn}, \mathrm{Mn}$ and $\mathrm{Pb}$ in the analysed soil samples 


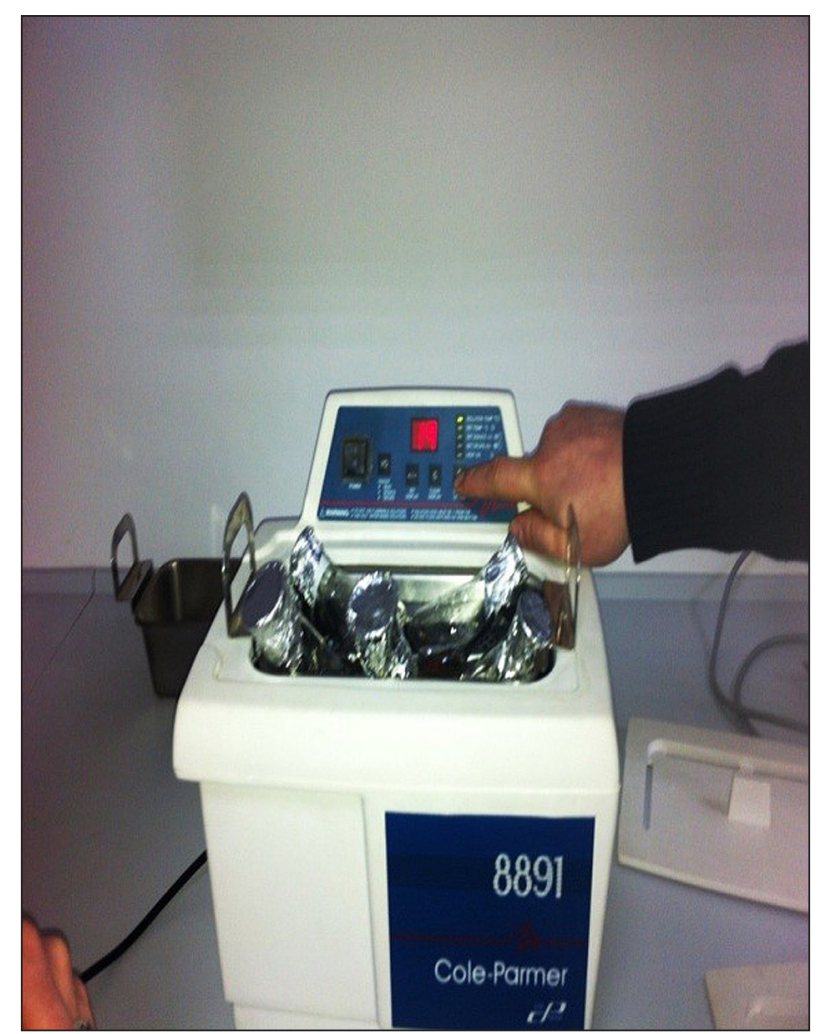

Figure 3. Contents of $\mathrm{Fe}, \mathrm{K}$ and $\mathrm{Al}$ in the analysed soil samples

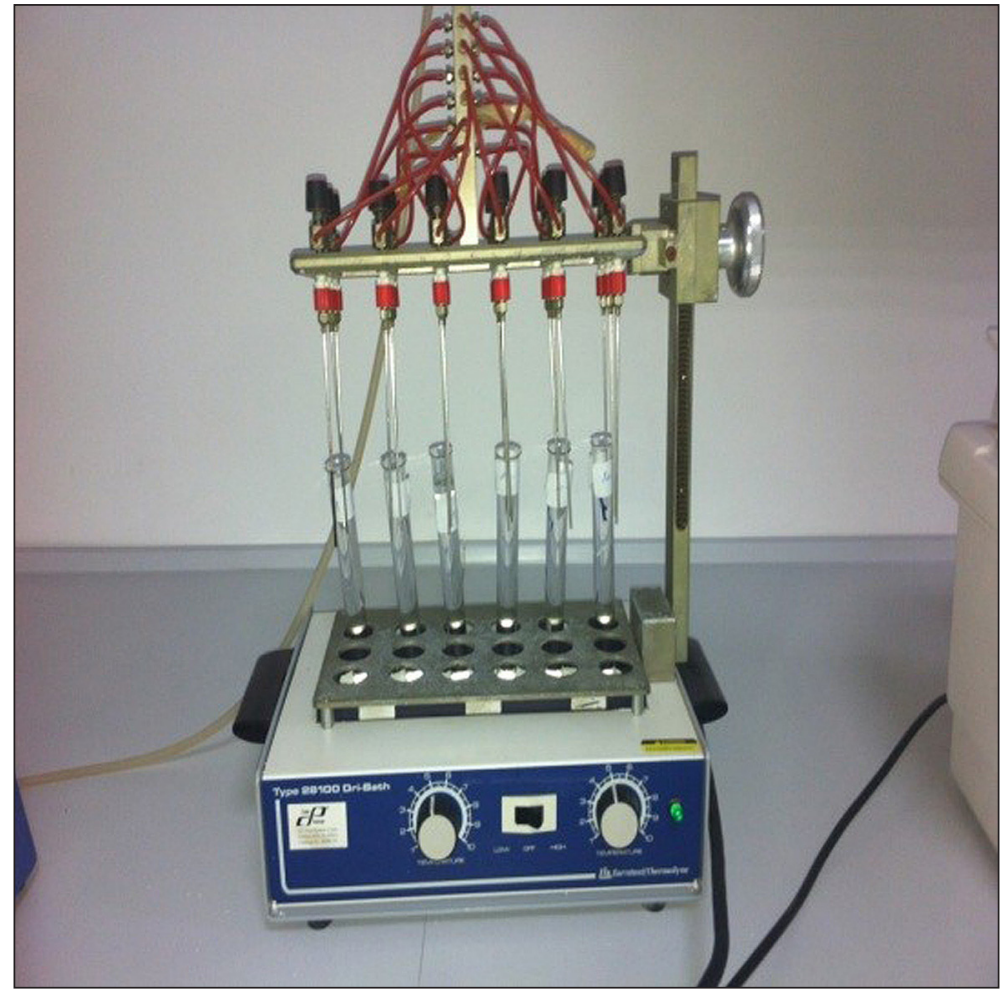

Figure 4. Contents of $\mathrm{Cr}, \mathrm{Cu}, \mathrm{Ba}$ and $\mathrm{Sr}$ in the analysed soil samples

allowed values, while the Mo values have varied from 3.2-13.1 and exceeded the critical values under VML in almost all sampling places (Vojnovc, Grackë, Kuzmin, Plementin uncultivated land
Pestova and before joining the Iber River), while the values of $\mathrm{Cu}$ in the analysed samples varied from $11.5-76.9 \mathrm{mg} / \mathrm{kg}$ and were within the allowed values. The variations expressed in the 
soil analysed samples were exhibited by $\mathrm{Fe}$ and $\mathrm{Al}$ where recorded values varied from 566.7 to 4866.7 for $\mathrm{Fe}$ and $2226-12254 \mathrm{mg} / \mathrm{kg}$ for Al.

The lowest values for all analysed elements were recorded in Devetak (sampling place near the source of the river and without anthropogenic influences). Meanwhile, higher values for the most of the elements, including $\mathrm{Cd}, \mathrm{Pb}, \mathrm{Mo}, \mathrm{Cu}, \mathrm{Zn}$, $\mathrm{Mn}$ and $\mathrm{Fe}$ were recorded in the sampling places before joining the Iber River, for $\mathrm{Ba}, \mathrm{K}$ and $\mathrm{Al}$ where the highest values were recorded in Grackë (this study area is characterized as agricultural area). For $\mathrm{Cr}$, the highest values were recorded in Kuzmin (which locality belongs to middle flow of Sitnica and is polluted by discharges of (urban) wastewater, while for Sr, the highest values were recorded at the sampling place in Plemetin in uncultivated land (this locality is under the influence of industrial emissions from mining coal surface in Mirash and Bardh, and ash emissions from the plant Thermo-central A and B to this part of the river).

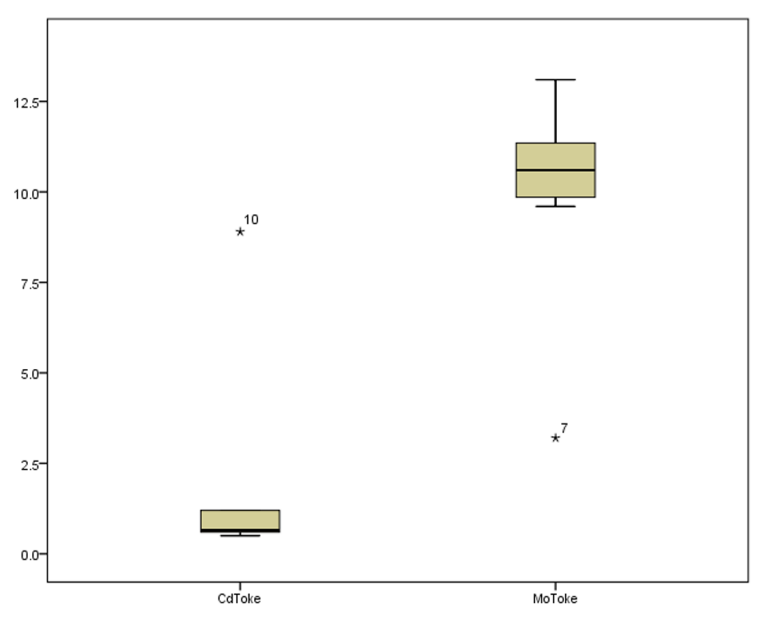

Graph. 1

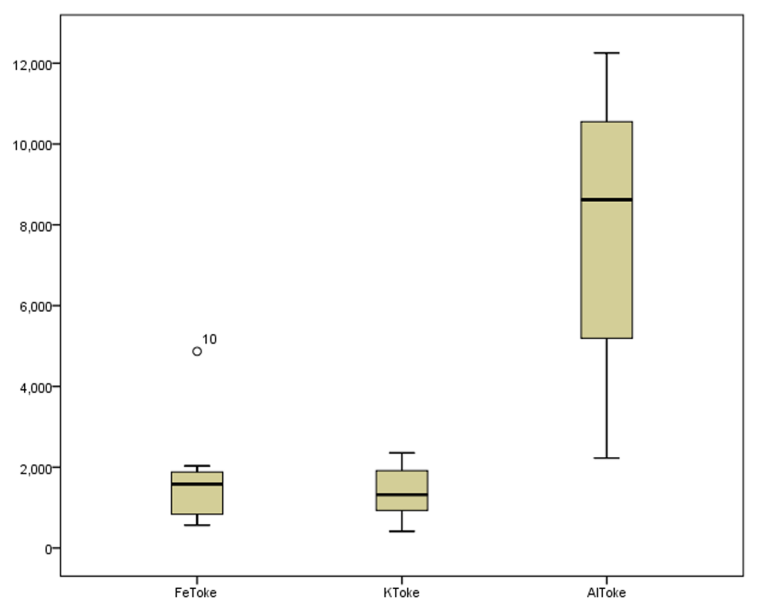

Graph. 3

\section{CONCLUSIONS}

After analysing the results, it can be concluded that the content of metals in the soil samples vary depending on the impact of pollution. Lower values for all analysed elements were recorded in Devetak (sampling place near the source of the river and without anthropogenic influences), while the values higher for most elements, including $\mathrm{Cd}, \mathrm{Pb}, \mathrm{Mo}, \mathrm{Cu}, \mathrm{Zn}, \mathrm{Mn}$ and Fe were recorded in the sampling places before joining the Iber River (locality under the influence of industrial emissions).

The analysed data in this study show high values of pollution from metals as in the samples taken in meadows as well as those in agricultural lands that lie around the river, followed the order $\mathrm{Al}>\mathrm{Fe}>\mathrm{K}>\mathrm{Mn}>\mathrm{Zn}>\mathrm{Pb}$. It was also noticed that the contents of heavy metals, such as $\mathrm{Zn}$, $\mathrm{Cd}, \mathrm{Pb}, \mathrm{Cr}$, in some analysed samples exceed the maximum allowed values.

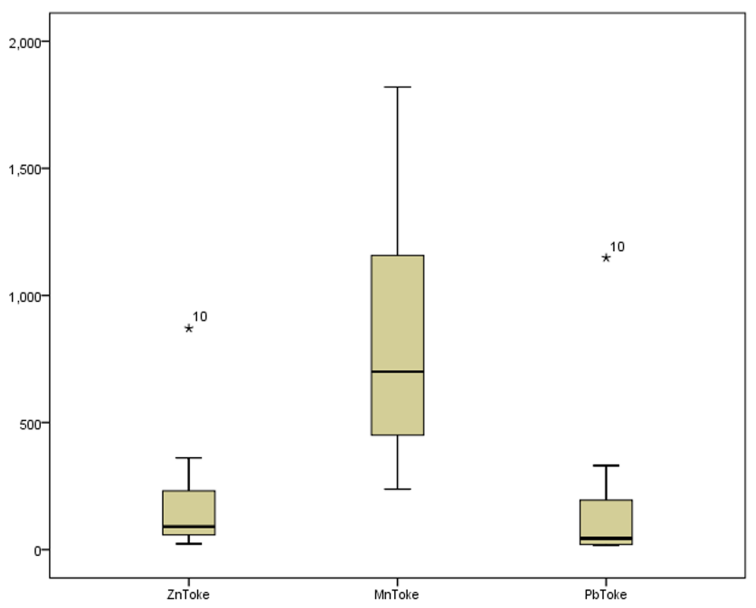

Graph. 2

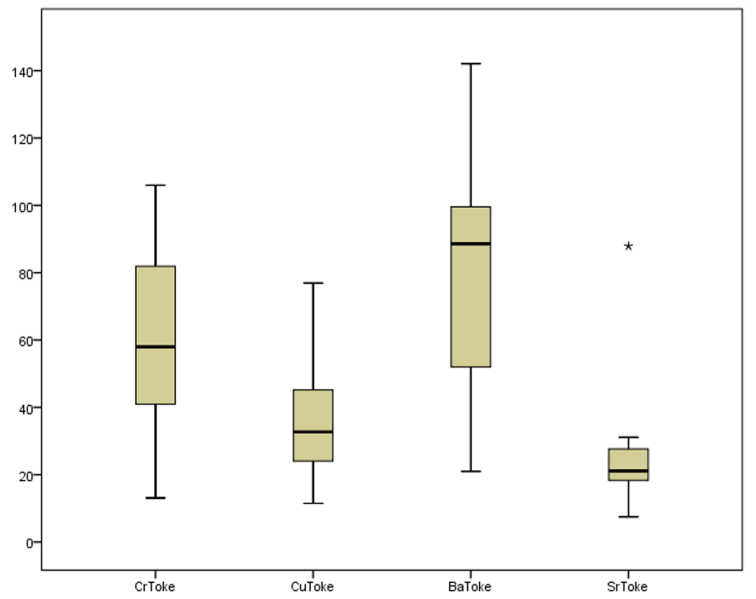

Graph. 4 
This paper provides a better view and more complete profile of the land pollution level along the Sitnica River with the metals influenced by the anthropogenic activity.

\section{REFERENCE}

1. Adriano D.C. 1984. Trace Metals in The Terrestrial Environment. VerlagSpiegler, New York.

2. Bargagli R. 1998. Trace elements in terrestrial plants. Anecophysiological approach to biomonitoring and biore-covery. Berlin: Springer.

3. Berglund S., Davis R.D., L'hermite P. 1984. Utilization of se Wage sludge on land: rates of application and long-term effects of metals. Dordrecht: D. Reidel Publishing, pp. 216.

4. Bichi M.H. 1999. Consequences of Environmental Degradation on Man and Habitat-A Focus on Environmental Pollution. In: Conference on Environmental Education. Bayero University Kano: Nigeria.

5. Colak H., Soylak M. and Turkoglu O. 2005. Determination of trace metal content of various herbal and fruit teas produced and marketedfrom Turkey. Trace. Elem. Electrolytes, 22, 192-195.

6. Dan'azumi S. and Bichi M.H.2010. Industrial Pollution and Implication on Source of Water Supply in Kano, Nigeria. International Journal of Engineering \& Technology, 10(1).

7. Divrikli U., Saracoglu S., Soylak M. and Elci L. 2003. Determination of trace heavy metal contents ofgreen vegetable samples from Kayseri-Turkey by flame atomic absorption spectrometry. Fresenius Environmental Bulletin (FEB), 12, 1123-1125.

8. Dundar M.S. and Saglam H.B. 2004. Determinationof cadmium and vanadium in tea varieties andtheir infusions in comparison with 2 infusion processes. Trace. Elem. Electrolytes, 21, 60-63.

9. Öztürk E., Atsan E., Polat T. and Kara K. 2011. Variation in heavy metal concentrations of potato (Solanumtuberosum L.) cultivars. The Journal of Animal \& Plant Sciences, 21(2), 235-239.
10. Ellen G., Loon J.W. and Tolsma K. 1990. Heavy metals in vegetables grown in the Netherlandsand in domestic and imported fruits. Z. Lebensm. Unters. Forsch., 190, 34-39.

11. Güleryüz G., Arslan H., İzgi B. and Güçer Ş. 2006. Element content $(\mathrm{Cu}, \mathrm{Fe}, \mathrm{Mn}, \mathrm{Ni}, \mathrm{Pb}$ and $\mathrm{Zn})$ of a ruderal plant species (Verbascum olympicum Boiss.) from East Medi-terranean. Zeitschrift für Naturforschung C, 61, 357-362.

12. Güleryüz G., Arslan H., Kırmızı S. and Güçer Ş. 2002. Investigation of influence of tungsten mine wastes on theelemental composition of some alpine and subalpine plantson Mount Uludağ, Bursa, Turkey. Environmental Pollution, 120, 707-716.

13. Kastrati B. 2014. Northeastern Kosovo: physic-geographical features and economic assessment of natural resources, Doctoral dissertation, Tirana.

14. Koch M. and Rotard W. 2001. On the contribution of background sources to heavy metal content of municipal sewage-sludge. Water Scienceand Technology, 43, 67-74.

15. Marschner H. 1995. Mineral nutrition of higher plants ( $2^{\text {nd }}$ ed.). Academic, London.

16. Mendil D., Tuzen M., Yazici K. and Soylak M. 2005. Heavy metals in lichens from roadsides and anindustrial zone in Trabzon, Turkey. Bull. Environ. Contam. Toxicol., 74, 190-194.

17. Narin I., Tuzen M., Sari H. and Soylak M. 2005. Heavy metal content of potato and corn chips fromTurkey. Bull. Environ. Contam. Toxicol., 74, 1072-1077.

18. Oktem F., Yavrucuoglu H., Turedi A. and Tunc B. 2005. The effect of nutritional habits onhematological parameters and trace elements in children. Suleyman Demirel Univ. Tip Fak. Der.,12, 6-10. (In Turkish).

19. Schroeder H.A. 1973. Pollution by industrial metals. In: Trace Elements and Nutrition Some positiveand Negative Aspects, Faber and Faber Lonson, pp. 119-128.

20. Slaveska R., Spirevska I., Stafilov T. and Ristov T. 1998. The content of trace metals in some herbal teas and their aqueous extracts. Acta Pharm., 48, 201-209. 